\title{
Status of scheduled castes in Punjab
}

\section{Amanpreet Kaur and Shalini Sharma}

Received: 23.09.2019; Revised: 22.10.2019; Accepted: 06.11.2019

See end of the paper for authors' affiliations Amanpreet Kaur Department of Sociology, GHG Institute of Law for Women, Sidhwan Khurad, Ludhiana (Punjab) India

Email : amansoc2016@gmail. com
ABSTRACT : A significant change has been occurred in the social status of scheduled castes. It includes change in their education, occupation and employment status, emigration to different countries, political participation (at Panchayati level), and change in their residence (from lehndey pase or outskirts of the village to in the village). The study based/relied upon various issues of Census of India, Economic Survey of Punjab, Economic and Statistical Organization, Punjab, Statistical Abstract of Punjab and data was obtained from the Department of Panchayats and Rural Development, Punjab. The study found that there is a significant change in the literacy rate from $1971(16.12 \%)$ to $2011(64.81 \%)$ and there is increase in the enrollment of SCs students in recognized institutes over the time. Percentage increase in the government jobs have been found but it is more in the class IV level jobs. Emigration and their political participation at grass root as well as state level play an important role in the change in their social status.

KEY WORDS: Untouchability, Caste system, Education

- HOW TO CITE THIS PAPER : Kaur, Amanpreet and Sharma, Shalini (2019). Status of scheduled castes in Punjab. Asian J. Home Sci., 14 (2) : 361-366, DOI: 10.15740/HAS/AJHS/14.2/361-366. Copyright@ 2019: Hind Agri-Horticultural Society. 